\title{
Analisis Sentimen Perusahaan Listrik Negara Cabang Ambon Menggunakan Metode Support Vector Machine dan Naive Bayes Classifier
}

\author{
Hennie Tuhuteru ${ }^{\left.1^{*}\right)}$, Ade Iriani $^{2}$ \\ ${ }^{1,2}$ Magister Sistem Informasi, Fakultas Teknologi Informasi, Universitas Kristen Satya Wacana, Salatiga \\ ${ }^{1,2} \mathrm{Jln}$. Diponegoro 52-60, Kota Salatiga, 50711, Indonesia \\ email: ${ }^{1}$ hannytuhuteru@gmail.com, ${ }^{2}$ adeiriani@gmail.com
}

Received: 30 Juli 2018; Revised: 1 Oktober 2018; Accepted: 20 Oktober 2018

Copyright $@ 2018$, Politeknik Harapan Bersama, Tegal

\begin{abstract}
Twitter is one of the most popular online networking service that accessed by the community / citizen. The account @ambonlima which has proven their credibility, take the opportunity to provide the information about the electricity in Ambon Island, Maluku. Power outage in Ambon is become the issue lately and the community conveyed via tweets addressed to $@$ ambonlima accounts such as complaints, criticisms or supports. The opinion is textual data which can be extracted to know the sentiment of society to the performance of PT. PLN Ambon. The purpose of this research is to to found out the sentimental level of the society about the electrical condition in Ambon by using sentiment analysis method. There are two classification method used in this research, Naive Bayes Classifier (NBC) dan Support Vector Machine (SVM). In this case, the researcher will compare both method to understand which method have better accuracy. The NBC classification results using 2 fold in validation process showed a better accuracy than other fold value, which is $67.2 \%$. Positive sentiment obtained $67 \%$, neutral sentiment $19 \%$ and negative sentiment $14 \%$. Meanwhile, the SVM classification method also showed a better accuracy using 2 fold. Positive sentiment derived $24 \%$, neutral sentiment $29 \%$, and negative sentiment $47 \%$. This study shows the average level of accuracy of SVM classification method is better than the NBC method, which is $76.42 \%$. The presence of negative sentiment that is not more than 50\% indicates the influence of account @ambonlima which is able to afford the electrical problems to the public in real time.
\end{abstract}

Abstrak - Media sosial Twitter saat ini menjadi layanan internet yang paling sering diakses oleh masyarakat. Hal ini dimanfaatkan oleh akun@ambonlima yang sudah teruji kredibilitasnya dalam menyediakan informasi sistem ketenagalistrikan di Pulau Ambon, Maluku. Pemadaman listrik yang terjadi di Pulau Ambon mengakibatkan banyaknya pendapat yang disampaikan melalui tweet yang ditujukan ke akun @ambonlima seperti keluhan, kritikan, maupun dukungan. Pendapat tersebut berupa data tekstual yang dapat diekstraksi untuk mengetahui sentiment masyarakat terhadap kinerja PT. PLN Cabang Ambon. Tujuan dari penelitian ini untuk mengetahui sentimen masyarakat di Pulau Ambon terhadap kondisi kelistrikan yang terjadi dengan menggunakan metode analisis sentimen. Metode klasifikasi sentimen yang digunakan, yaitu Naive Bayes Classifier (NBC) dan

*) Corresponding author: (Hennie Tuhuteru)

Email: hannytuhuteru@gmail.com
Support Vector Machine (SVM). Perbandingan performa dari kedua metode ini juga dilakukan untuk mengetahui mana yang memiliki akurasi yang lebih baik. Hasil yang diperoleh menggunakan metode klasifikasi NBC dengan 2 fold pada proses validasi menunjukkan tingkat akurasi yang lebih baik dibandingkan dengan nilai fold yang lain, yaitu sebesar 67.2\% . Sentimen positif yang diperoleh dari klasifikasi NBC sebesar $67 \%$, sentimen netral $19 \%$, dan sentimen negatif $14 \%$. Sementara itu, hasil analisis menggunakan metode klasifikasi SVM juga memiliki akurasi yang lebih baik ketika menggunakan 2 fold. Sentimen positif yang diperoleh dari penggunaan metode SVM sebesar $24 \%$, sentimen netral $29 \%$, dan sentimen negatif $47 \%$. Penelitian ini menunjukan rata-rata tingkat akurasi metode klasifikasi SVM yang lebih baik dari pada metode NBC, yaitu sebesar $\mathbf{7 6 . 4 2 \%}$. Adanya sentimen negatif yang tidak lebih dari 50\% menunjukkan pengaruh akun@ambonlima yang mampu memberikan informasi masalah kelistrikan kepada masyarakat secara realtime.

Kata Kunci - Analisis Sentimen, Naive Bayes Classifier, Support Vector Machine, Twitter.

\section{PENDAHULUAN}

Internet saat ini telah menjadi bagian terpenting dalam kehidupan sehari-hari masyarakat di dunia, tak terkecuali di Indonesia. Peningkatan presentase jumlah pengguna internet dari tahun ke tahun menjadi indikatornya. Media sosial menjadi layanan internet yang paling sering diakses oleh masyarakat Indonesia, salah satunya adalah Twitter [1], [2]. Pemanfaatan Twitter untuk layanan publik sebagai sarana penyampaian berbagai informasi terbaru, akan memberikan dampak positif bagi masyarkat. Seperti salah satu akun Twitter, @ambonlima, yang menyediakan informasi sistem ketenagalistrikan di Pulau Ambon, Provinsi Maluku, Indonesia.

Pemadaman listrik di Ambon terjadi karena berbagai faktor, seperti misalnya pemeliharaan jaringan, gangguan kabel, gangguan gardu, bencana alam atau defisit daya [3]. Hal ini mengakibatkan banyaknya 'cuitan' atau pendapat dari masyarakat berupa keluhan, kritikan, dan juga dukungan terhadap PT. Perusahaan Listrik Negara (PLN) (Persero) sebagai penyedia layanan kelistrikan di Indonesia. Pendapat yang berupa data tekstual tersebut memiliki pengetahuan 
tersembunyi yang dapat diekstraksi dengan text mining menggunakan seperangkat tools analisis [4], [5]. Proses ini dilakukan dengan pendekatan opinion mining atau analisis sentimen.

Analisis sentimen akan membantu dalam hal prediksi, menganalisis suasana publik, menggambarkan keseluruhan perasaan secara otomatis, kecenderungan dan suasana hati seseorang atau konsumen pada masalah sosial tertentu karena berfokus pada analisis dan pemahaman emosi dari review pola teks [6], [7]. Analisis sentimen dapat diterapkan untuk mengetahui bagaimana sentimen atau pandangan masyarakat terhadap masalah kelistrikan yang terjadi di Pulau Ambon. Proses ini perlu dilakukan karena bisa menjadi bahan evaluasi bagi PT. PLN (Persero) khususnya cabang Ambon untuk memperbaiki ataupun meningkatkan kinerja dan layanan kelistrikan bagi masyarakat, demi terciptanya keadilan sosial bagi seluruh rakyat yang menjadi salah satu landasan negara Indonesia.

Berdasarkan latar belakang tersebut, maka dilakukan penelitian dengan tujuan untuk mengetahui bagaimana sentimen masyarakat di Pulau Ambon terhadap kondisi kelistrikan, khususnya pemadaman listrik yang terjadi dengan menggunakan metode analisis sentimen. Penelitian ini menggunakan metode klasifikasi Naive Bayes Classifier (NBC) dan Support Vector Machine (SVM) untuk menentukan sentimen masyarakat terhadap masalah penelitian ini. NBC dipilih karena termasuk metode klasifikasi probabilistik sederhana dan sangat berguna untuk sekumpulan dataset yang besar, serta merupakan penggolongan klasifikasi yang paling banyak digunakan [8][9][10]. Sementara metode klasifikasi SVM digunakan untuk perbandingan tingkat akurasi dan waktu eksekusi.

\section{PENELITIAN YANG TERKAIT}

Penelitian tentang analisis sentimen sudah dilakukan sebelumnya, seperti yang dilakukan oleh Ozturk dan Ayvaz, dengan judul "Sentiment Analysis on Twitter: A Text Mining Approach to the Syrian Refugee Crisis" [11]. Pada penelitian ini, dilakukan analisis mengenai pendapat dan sentiment publik terhadap masalah krisis pengungsi dari negara Suriah yang mempengaruhi jutaan orang dan dibahas secara luas melalui media sosial diseluruh dunia. Data yang dikumpulkan berasal dari media sosial Twitter dengan menggunakan twitteR package yang ditulis dalam bahasa pemrograman $\mathrm{R}$. Data diambil merupakan tweet dalam Bahasa Inggris dengan keyword "Syrian" dan "refugee", serta Bahasa Turki dengan keyword "Suriyeli", "mülteci" dan "multeci" dengan total data yang relevan 348.707 dari 2.381.197 data. Bahasa Turki juga dipilih karena negara ini menampung pengungsi Suriah dalam jumlah besar sehingga sering didiskusikan di Twitter. Data yang ada kemudian melalui tahap pre-processing untuk penyaringan dataset. Proses klasifikasi selanjutnya menggunakan sebuah package di R, RSentiment package untuk analisis sentimen dalam Bahasa Inggris. Sedangkan untuk analisis sentimen dalam Bahasa Turki, peneliti mengembangkan lexicon sentimen karena tidak ada lexicon komprehensif. Hasil yang diperoleh menunjukan perbedaan yang signifikan antara tweet dalam Bahasa Inggris dan Bahasa Turki. Tweet dalam Bahasa Turki mencapai sentimen positif yang lebih banyak terhadap warga suriah dan pengungsinya daripada sentimen netral dan negatif, namun hampir merata disetiap kategori dengan masing sentimen positif $35 \%$, sentimen negatif $34 \%$, dan sentimen netral $31 \%$. Sementara tweet dalam Bahasa Inggris mengandung lebih banyak sentimen netral, yaitu $48 \%$ diikuti oleh sentimen negatif $40 \%$ dan sentimen positif $12 \%$ [11].

Penelitian yang dilakukan tentang analisis sentimen juga dilakukan oleh Zulfa dan Winarko pada jurnalnya yang berjudul "Sentimen Analisis Tweet Berbahasa Indonesia dengan Deep Belief Network" [12]. Tujuan dari penelitian yang sudah dilakukan adalah untuk melakukan proses klasifikasi sentimen positif, negatif dan netral terhadap data uji serta akurasi model klasifikasinya dengan metode Deep Belief Network (DBN) untuk menandai sentimen data latih tweet berbahasa Indonesia. Selain DBN, metode lain seperti Naive Bayes Classifier (NBC) dan Support Vector Maching (SVM) juga digunakan dalam proses klasifikasi untuk membandingkan tingkat akurasi dari masing-masing metode tersebut. Data yang dikumpulkan sejumlah 2378 tweet dan berasal dari kumpulan tweet yang lagi tren, berupa tweet terbanyak tentang kata tertentu, di Indonesia sesuai sistem pencarian Twitter. Data kemudian dibagi sesuai dengan trennya yaitu \#AhokDijegal, \#JakartaKece, \#Menuju412, \#SalamBudaya, \#SidangAhok, \#SubuhBerjamaah1212, Anies dan Hari Bebas Kendaraan Bermotor. Hasil analisis sentimen secara keseluruhan dari penelitian ini yaitu positif $26.99 \%$, negatif $21.73 \%$ dan sisanya netral $50.91 \%$. Hasil akurasi yang diperoleh dari perhitungan klasifikasi dengan menggunakan metode DBN yaitu sebesar $93.31 \%$, dengan presisi $93 \%$, recall 93\% dan fl-score 93\%. Hasil perhitungan akurasi yang diperoleh dengan menggunakan metode SVM tidak berbeda jauh dengan metode DBN yaitu sebesar $92.18 \%$, dengan presisi $92 \%$, recall $92 \%$ dan fl-score $92.18 \%$. Sedangkan hasil akurasi yang diperoleh menggunakan NBC memiliki perbedaan yang signifikan dengan kedua metode sebelumnya, yaitu sebesar $79.10 \%$, dengan presisi $79 \%$, recall $79 \%$ dan fl-score $79 \%$ [12].

Analisis sentimen juga telah dibahas oleh Tripathi, dkk tentang tweet berbahasa inggris menggunakan RapidMiner [9]. Data yang dikumpulkan berasal dari tweet bahasa sehari-hari dan diterapkan teknik text mining pada dataset training dan testing, seperti Tokenize, filter tokens, transform case, filter stopwords, stemming. Hasil dari proses tersebut kemudian digunakan untuk pengklasifikasian sentimen yang dapat memprediksi sentimen senang, sedih, dan netral. Pada penelitian ini juga digunakan dua metode klasifikasi, yaitu NBC dan K-Nearest Neighbor (K-NN). Kedua metode ini digunakan untuk membandingkan hasil yang diperoleh sehingga dapat diketahui metode mana yang memberikan hasil terbaik. Dari hasil penelitian yang telah dilakukan, diketahui K-NN menghasilkan nilai prediksi akurasi yang lebih baik dari NBC sehingga dapat diasumsikan bahwa K-NN merupakan metode klasifikasi yang terbaik pada kasus yang diteliti [9].

Penelitian sebelumnya yang telah dilakukan membuktikan bahwa analisis sentimen berhasil diterapkan untuk mengetahui sentimen masyarakat terhadap suatu masalah yang menjadi topik utama pembicaraan. Berdasarkan hal tersebut, maka dilakukan penelitian mengenai analisis sentimen masyarakat di Pulau Ambon, Maluku terhadap masalah kelistrikan, terutama masalah pemadaman listrik yang terjadi. Penelitian ini berbeda dengan penelitian sebelumnya terletak pada dataset yang digunakan, dimana data tweet menggunakan bahasa Melayu 
Ambon sehingga perlu diterjemahkan kedalam Bahasa Indonesia agar lebih mudah dipahami. Metode klasifikasi sentimen pada penelitian ini menggunakan dua metode, yaitu Naive Bayes Classifier (NBC) dan Support Vector Machine (SVM) sebagai perbandingan.

\section{ANALISIS SENTIMEN}

Menurut Liu, analisis sentimen merupakan suatu bidang studi yang menganalisis pendapat, sentimen, evaluasi, penilaian, sikap dan emosi terhadap entitas seperti produk, layanan, organisasi, suatu masalah, peristiwa, topik dan attributnya [13]. Analisis sentimen juga merupakan sebuah bidang penelitian baru didalam Natural Language Processing (NLP) dengan tujuan untuk mendeteksi subjektivitas pada teks dan/atau mengekstraksi dan melakukan klasifikasi terhadap pendapat dan sentimen [14].

Dalam metode klasifikasi sentimen terdapat tiga teknik yaitu Machine Learning, Lexicon Based, dan Hybrid Approach [14][15]. Penelitian analisis sentimen yang dilakukan saat ini menggunakan pendekatan Machine Learning karena pendekatan ini digunakan untuk memprediksi polaritas sentimen berdasarkan data yang sudah dilatih sesuai dengan data tes [14]. Proses dalam review analisis sentimen seperti yang digambarkan oleh Bhonde \& Prasad secara berturut-turut yaitu Teks tidak terstruktur, meliputi data teks yang diperoleh dari blogs, tweets, forum, dan reviews; Data Pre-pocessing, meliputi proses stemming, stopword removal dan proses tokenisasi; Sentiment term identification; serta klasifikasi sentimen; [15].

\section{A. Data Pre-processing}

Proses pengumpulan data teks yang berupa opini dari media sosial seperti Twitter dan Facebook memiliki tantangan tersendiri karena bahasa yang digunakan tidak sesuai dengan kata baku, disingkat, menggunakan bahasa daerah, bahkan kata-kata yang tidak ada di dalam kamus. Data Pre-processing disebut juga Normalisasi, diperlukan untuk mengatasi hal ini dengan tujuan untuk mengembalikan sebanyak mungkin bahasa pesan ke bahasa alami dengan menghilangkan ekspresi atipikal sehingga dapat meminimalkan noise pada tahapan selanjutnya [16]. Proses pre-processing dilakukan melalui beberapa tahapan, yaitu case folding; Penghapusan simbolsimbol atau tanda baca; tokenisasi; konversi slangword; penghapusan stopword; serta stemming (mengubah kata imbuhan menjadi kata dasar); [12], [15], [16].

\section{B. Term Weighting}

Term Weighting merupakan cara atau strategi yang dilakukan untuk menentukan bobot pada suatu kata sehingga dapat meningkatkan kinerja analisis sentimen dan proses teks mining lainnya pada kategorisasi teks [17][18]. Pada proses ini dilakukan teknik pembobotan menggunakan Term FrequencyInverse Document Frequency (TF-IDF). Term Frequency $(\mathrm{tf}(\mathrm{w}, \mathrm{d}))$ merupakan berapa kali sebuah kata ada didalam sebuah dokumen d. Sedangkan ukuran TF-IDF merupakan statistik yang menunjukkan pentingnya sebuah kata tersebut didalam sebuah dataset atau dokumen [15]. TF-IDF dapat dirumuskan sebagai berikut [19]:

$$
T F-I D F_{t, d}=T F_{t, d} \times I D F_{t}
$$

$$
\begin{array}{ll}
\text { Dimana, IDF } & =\log \frac{N}{D F_{t}} \\
t & =\text { kata-kata yang dihitung; } \\
d & =\text { bobot kalimat }(d) ; \\
T F-I D F_{t, d} & =\text { kalimat bobot }(d) \text { terhadap kata }(t) ; \\
T F_{t, d} & =\text { Term Frequency; } \\
I D F_{t} & =\text { Inverse Document Frequency; } \\
N & =\text { jumlah kalimat; } \\
D F_{t} & =\text { jumlah kata yang diulang; }
\end{array}
$$

\section{Naive Bayes Classifier (NBC)}

Naive Bayes Classifier (NBC) merupakan salah satu metode pembelajaran probabilitas pada Machine Learning yang beranggapan bahwa setiap kata terjadi secara independen [19][20][21]. NBC memodelkan distribusi dokumen disetiap kelas menggunakan sebuah model probabilitas dengan asumsi independensi tentang distribusi dari kata-kata yang berbeda [8]. Metode ini didasari oleh Thomas Bayes, seorang ilmuwan asal Inggris yang memperkenalkan Teorema Bayes yaitu memprediksi peluang dimasa depan berdasarkan pengalaman dimasa lalu [20][21]. Dalam penerapannya pada analisis sentimen, pengalaman dimasa lalu dianalogikan sebagai data training dan masa depan sebagai data testing. NBC dapat dirumuskan sebagai berikut [19]:

$$
P\left(c_{k} \mid d_{j}\right)=P\left(c_{k}\right) \prod_{i=1}^{T} P\left(t_{i} \mid c_{k}\right)
$$

Dimana, $P\left(t_{i} \mid c_{k}\right)$ merupakan probabilitas bersyarat dari kata $t_{i}$ yang terjadi di dalam dokumen dari kelas $c_{k} ; P\left(c_{k}\right)$ merupakan probabilitas sebelumnya dari dokumen yang terjadi didalam kelas $c_{k} . P\left(t_{i} \mid c_{k}\right)$ dan $P\left(c_{k}\right)$ diperkirakan dari data training [19]

\section{Support Vector Machine (SVM)}

Support Vector Machine (SVM) merupakan salah satu teknik pembelajaran supervised dengan kualitas dan akurasi baik yang membuatnya menjadi algoritma populer diantara algoritma lainnya [19]. "Klasifikasi SVM berupaya untuk mempartisi ruang data dengan menggunakan penggambaran linier atau non-linier antara kelas yang berbeda" [8]. Dalam geometri, SVM dapat dilihat sebagai hyperplane pada fitur ruang yang memisahkan titik-titik yang mewakili kategori dari hal positif dan dari titik-titik yang mewakili hal negatif [5].

Prinsip utama dari SVM adalah untuk menentukan ruang pemisah di ruang pencarian yang dapat memisahkan kelaskelas yang berbeda [8]. Proses SVM dimulai dari mengubah data text kedalam bentuk vector data dan dikombinasikan dengan nilai TF-IDF untuk pembobotan [22]. [23]:

Fungsi deskriptif dari SVM dapat dilihat sebagai berikut

$$
h(X)=z^{x} \emptyset(X)+c
$$

Dimana X merupakan fitur vector, $\mathrm{z}$ merupakan vector dari bobot yang berbeda, $\varnothing$ merupakan fungsi pemetaan non-linier, dan $\mathrm{c}$ adalah vector bias. $\mathrm{z}$ dan $\mathrm{c}$ diperoleh secara otomatis dari dataset training [23]. 


\section{METODE PENELITIAN}

Penelitian mengenai analisis sentimen ini dilakukan melalui beberapa tahapan seperti yang terlihat pada Gbr 1 .

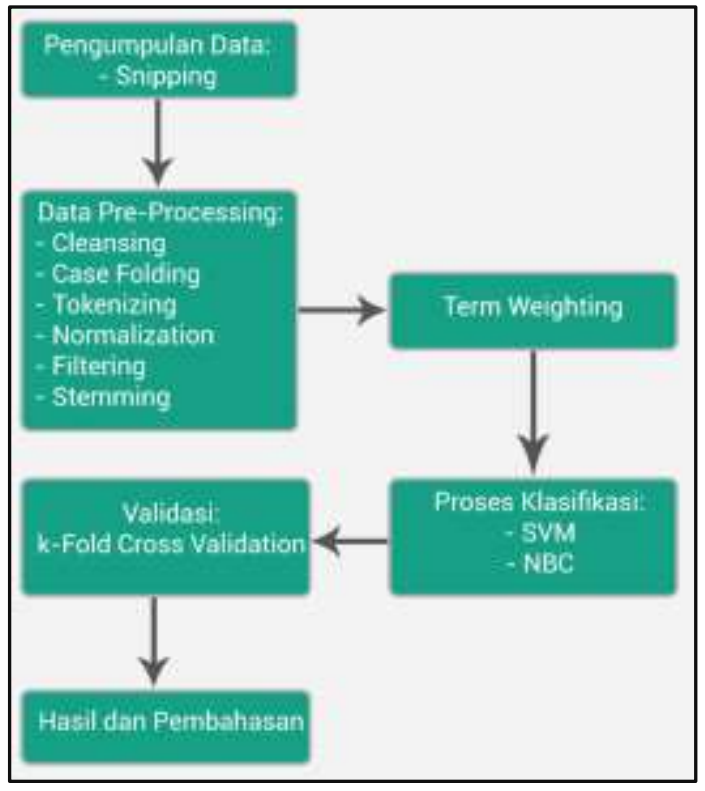

Gbr. 1 Tahapan Penelitian Analisis Sentimen

\section{1) Pengumpulan Data}

Proses pengumpulan data dilakukan dengan mengambil data tweet dari akun Twitter yang mention ke akun '@ambonlima', sebagai penyedia informasi ketenagalistrikan di Pulau Ambon. Selain itu, data juga dikumpulkan menggunakan pencarian dengan keyword "PLN Ambon". Data diambil dengan metode snipping dengan total 1491 tweet, sejak 1 Januari 2015 hingga 30 April 2018. Data kemudian dibagi dua sesuai dengan pendekatan machine learning, menjadi data training sejumlah 491 tweet dan data testing sejumlah 1000 tweet. Proses klasifikasi dengan SVM dan NBC menggunakan dataset yang sama.

\section{2) Data Pre-processing}

Pre-processing dilakukan pada data training untuk membantu proses pembelajaran algoritma. Proses ini dilakukan untuk mengubah data yang tidak terstruktur menjadi data terstruktur sehingga dapat mempermudah pemrosesan data. Tweet dalam bahasa daerah, khususnya bahasa Ambon akan diterjemahkan ke bahasa Indonesia sehingga data yang akan diproses dapat diselaraskan menjadi bahasa Indonesia. Text pre-processing pada penelitian ini dilakukan melalui 6 tahapan, yaitu:

a) Cleansing: Cleansing merupakan proses penghapusan karakter non-alfabetis untuk mengurangi noise. Karakter yang dihapus berupa tanda baca, simbol-simbol seperti tanda '@' untuk nama pengguna, hashtag (\#), emoticon dan url dari situs web.

b) Case Folding: Proses ini dilakukan dengan mengubah semua karakter alfabet yang sudah dibersihkan sebelumnya menjadi huruf kecil (lower case).

c) Tokenizing: Tokenizing merupakan proses pemisahan kata-kata dari kalimat penyusunnya, yang nantinya disebut token atau term. d) Normalization: Tahap ini dilakukan untuk menormalkan kata-kata yang disingkat ataupun diperpanjang menjadi kata-kata normal sesuai dengan Kamus Besar Bahasa Indonesia (KBBI). Pada tahap ini juga digunakan operator Replace Token dari RapidMiner untuk menerjemahkan kata dalam bahasa daerah Ambon ke Bahasa Indonesia. Hal ini penting dilakukan karena tweet yang dikumpulkan menggunakan bahasa lokal selain Bahasa Indonesia.

e) Filtering: Kata-kata yang sering muncul secara umum dan kurang relevan dengan teks akan dihapus. Tahap ini disebut juga dengan stopword removing, yaitu menghapus kata-kata yang tidak bermakna dan tidak memiliki pengaruh terhadap analisis sentimen.

f) Stemming: Proses ini dilakukan untuk mengubah kata berimbuhan dari setiap kata yang sudah disaring menjadi kata dasar.

\section{3) Term Weighting}

Proses Term Weighting atau pembobotan setiap kata yang dilakukan pada penelitian ini menggunakan TF-IDF. Implementasinya pada aplikasi RapidMiner dilakukan menggunakan operator Process Document from Data yang merupakan salah satu ekstensi dari Text Processing.

\section{4) Proses Klasifikasi}

Proses klasifikasi pada penelitian ini menggunakan metode SVM dan NBC. Proses ini dilakukan setelah dilakukannya pembobotan pada setiap kata.

\section{5) Validasi}

$K$-fold Cross Validation merupakan salah satu metode pada proses validasi yang digunakan untuk memperkirakan kinerja sesungguhnya dari model machine learning. Proses validasi pada penelitian ini dilakukan menggunakan $K$-Fold Cross Validation untuk menghilangkan bias atau noise kata sehingga dapat meningkatkan tingkat akurasi. Pada $K$-fold cross validation terdapat mekanisme keacakan yang menyebabkan akurasi rata-rata yang dihasilkan pada kumpulan data menjadi tidak konstan [24]. Hal ini dapat dimanfaatkan untuk menentukan angka fold terbaik sesuai dengan akurasi yang dihasilkan dari masing-masing classifier.

\section{6) Hasil dan Pembahasan}

Setelah tahap pengumpulan data, pre-processing, pembobotan kata, proses klasifikasi hingga tahap validasi dilakukan, maka akan didapatkan hasil analisis sentimen. Hasil ini ditampilkan dan dibahas pada bab selanjutnya.

\section{HASIL DAN PEMBAHASAN}

Proses analisis sentimen pada penelitian ini dilakukan dengan menggunakan RapidMiner Studio 8.2.000 dengan tambahan ekstensi Text Processing. Sentimen pada data training sejumlah 491 dibagi secara manual sesuai kelasnya seperti yang ditunjukan pada Tabel I. Data training tersebut kemudian akan melalui tahap pre-processing. Sebagai contoh, diambil 2 tweet yang dianggap dapat mewakili pre-processing ini seperti yang terlihat pada Gbr 2. Contoh penerapan preprocessing pada tweet ditunjukan pada Tabel II. Tweet pertama diberi label $\mathrm{T} 1$ dan tweet kedua diberi label $\mathrm{T} 2$. Jumlah term 
atau kata yang ditemukan sebelum pre-processing sejumlah 1304.

TABEL I

SENTIMEN DATA TRAINING

\begin{tabular}{|c|c|c|c|}
\hline Positif & Netral & Negatif & Jumlah \\
\hline $\mathbf{1 2 5}$ & 158 & 208 & 491 \\
\hline $\mathbf{2 5 . 4 6} \%$ & $32.18 \%$ & $42.36 \%$ & $100 \%$ \\
\hline
\end{tabular}

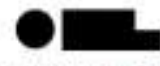

PLN EEEEE gimbonlima ...... KATONG SU KAYAK HIDUP DI JAMAN PRIMITIF SAIA EEEEEE.

S-
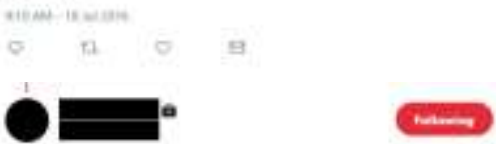

Kmm tlvn k 123 katanya tak ada laporan pemadaman. Skrg sistem aman! Bgmn ni? Sedang lampu padam drtd! Kaco ee

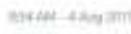

o.

Gbr. 2 Contoh tweet tentang masalah kelistrikan di Pulau Ambon

TABEL II

CONTOH HASIL PRE-PROCESSING

\begin{tabular}{|l|l|}
\hline Tahap Pre-processing & \multicolumn{1}{|c|}{ Hasil } \\
\hline Cleansing & T1: PLN EEEEE KATONG SU KAYAK \\
& HIDUP DI JAMAN PRIMITIF SAJA \\
& EEEEEE. \\
& T2: Kmrn tlvn k katanya 398aka da laporan \\
pemadaman Skrg sistem aman Bgmn ni & Sedang lampu padam drtd Kaco ee
\end{tabular}

Setelah proses pre-processing dilakukan maka dilanjutkan dengan proses pembobotan atau term weighting berdasarkan fitur TF-IDF. Beberapa kata diambil sebagai contoh atribut penentuan data termasuk dalam kategori positif seperti nyala, terima kasih, keren; kategori negatif seperti padam, aduh, kesal, gangguan, parah; atau kategori netral. Hasil pengolahan data teks pada atribut tersebut menghasilkan bobot nilai yang berada didalam masing-masing data tweet yang kemudian dibandingkan setiap probabilitasnya berdasarkan pembobotan TF-IDF. Pembobotan ini terlihat pada Tabel III dan Tabel IV.

TABEL III

ATRIBUT KATEGORI POSITIF

\begin{tabular}{|l|l|l|l|l|l|l|}
\hline $\begin{array}{l}\text { Doku- } \\
\text { men }\end{array}$ & nyala & $\begin{array}{l}\text { terima } \\
\text { kasih }\end{array}$ & keren & $\begin{array}{l}\text { norma } \\
\text { l }\end{array}$ & $\begin{array}{l}\text { sema } \\
\text {-ngat }\end{array}$ & Prob. \\
\hline $\begin{array}{l}\text { Negatif } \\
\mathbf{1 3}\end{array}$ & 0.170 & 0.000 & 0.000 & 0.000 & 0.000 & 0.170 \\
\hline $\begin{array}{l}\text { Negatif } \\
\mathbf{5 0}\end{array}$ & 0.000 & 0.000 & 0.000 & 0.000 & 0.000 & 0.000 \\
\hline $\begin{array}{l}\text { Negatif } \\
\mathbf{1 7 8}\end{array}$ & 0.000 & 0.000 & 0.000 & 0.000 & 0.000 & 0.000 \\
\hline Positif 53 & 0.239 & 0.000 & 0.000 & 0.000 & 0.000 & 0.239 \\
\hline Positif 93 & 0.000 & 0.000 & 0.000 & 1.000 & 0.000 & 1.000 \\
\hline $\begin{array}{l}\text { Positif } \\
\mathbf{1 0 0}\end{array}$ & 0.000 & 0.909 & 0.000 & 0.000 & 0.000 & 0.909 \\
\hline $\begin{array}{l}\text { Netral } \\
\mathbf{1 1 2}\end{array}$ & 0.000 & 0.000 & 0.000 & 0.000 & 1.000 & 1.000 \\
\hline
\end{tabular}

TABEL IV

ATRIBUT KATEGORI NEGATIF

\begin{tabular}{|l|l|l|l|l|l|l|}
\hline Dokumen & padam & aduh & kesal & gangguan & parah & Prob. \\
\hline Negatif 13 & 0.182 & 0.000 & 0.000 & 0.530 & 0.000 & 0.712 \\
\hline Negatif 50 & 0.000 & 0.000 & 0.799 & 0.000 & 0.000 & 0.799 \\
\hline $\begin{array}{l}\text { Negatif } \\
\text { 178 }\end{array}$ & 0.091 & 0.923 & 0.000 & 0.000 & 0.000 & 1.014 \\
\hline Positif 53 & 0.128 & 0.000 & 0.000 & 0.000 & 0.000 & 0.128 \\
\hline Positif 93 & 0.000 & 0.000 & 0.000 & 0.000 & 0.000 & 0.000 \\
\hline Positif 100 & 0.418 & 0.000 & 0.000 & 0.000 & 0.000 & 0.418 \\
\hline Netral 112 & 0.000 & 0.000 & 0.000 & 1.000 & 0.000 & 1.000 \\
\hline
\end{tabular}

TABEL V

PENENTUAN KELAS SENTIMEN

\begin{tabular}{|l|l|l|l|}
\hline Dokumen & Prob. Positif & Prob. Negatif & Class \\
\hline Negatif 13 & 0.170 & 0.712 & Negatif \\
\hline Negatif 50 & 0.000 & 0.799 & Negatif \\
\hline Negatif 178 & 0.000 & 1.014 & Negatif \\
\hline Positif 53 & 0.239 & 0.128 & Positif \\
\hline Positif 93 & 1.000 & 0.000 & Positif \\
\hline Positif 100 & 0.909 & 0.418 & Positif \\
\hline Netral 112 & 1.000 & 1.000 & Netral \\
\hline
\end{tabular}

Tabel III dan Tabel IV menunjukkan probabilitas tiap dokumen berdasarkan atributnya masing-masing. Hasil dari probabilitas dengan atribut positif dan atribut negatif ini kemudian dibandingkan untuk mengetahui mana yang memiliki probabilitas lebih besar seperti yang terlihat pada Tabel V. Jika probabilitas opini negatif lebih besar daripada opini positif, maka ditetapkan dokumen tersebut merupakan opini negatif. Sebaliknya, jika probabilitas opini positif lebih besar daripada opini negatif, maka ditetapkan dokumen 
tersebut merupakan opini positif. Jika opini negatif dan opini positif memiliki probabilitas nilai yang sama, maka ditetapkan dokumen tersebut termasuk kategori opini netral.

\section{A. Analisis Data Menggunakan Naive Bayes Classifier (NBC)}

Hasil pengujian data dengan menggunakan metode klasifikasi NBC dapat dilihat pada Tabel VI. Pengujian dilakukan sebanyak 8 kali dengan mengubah nilai fold pada cross validation dan memperhatikan akurasi yang diperoleh.

TABEL VI

PRESENTASE HASIL PENGUJIAN MENGGUNAKAN NBC

\begin{tabular}{|c|l|l|l|l|}
\hline K-Fold & Accuration & $\begin{array}{l}\text { Weighted } \\
\text { Mean } \\
\text { Recall }\end{array}$ & $\begin{array}{l}\text { Weighted Mean } \\
\text { Precision }\end{array}$ & $\begin{array}{l}\text { Execution } \\
\text { Time }\end{array}$ \\
\hline $\mathbf{2}$ & $67.20 \%$ & $71.31 \%$ & $75.64 \%$ & 20 detik \\
\hline $\mathbf{3}$ & $63.34 \%$ & $67.54 \%$ & $72.80 \%$ & 14 detik \\
\hline $\mathbf{4}$ & $62.73 \%$ & $67.11 \%$ & $72.91 \%$ & 12 detik \\
\hline $\mathbf{5}$ & $61.92 \%$ & $66.32 \%$ & $72.91 \%$ & 14 detik \\
\hline $\mathbf{6}$ & $61.34 \%$ & $65.80 \%$ & $72.09 \%$ & 13 detik \\
\hline $\mathbf{7}$ & $61.24 \%$ & $65.66 \%$ & $72.41 \%$ & 13 detik \\
\hline $\mathbf{8}$ & $61.01 \%$ & $65.49 \%$ & $72.19 \%$ & 20 detik \\
\hline $\mathbf{1 0}$ & $60.94 \%$ & $65.42 \%$ & $72.06 \%$ & 22 detik \\
\hline
\end{tabular}

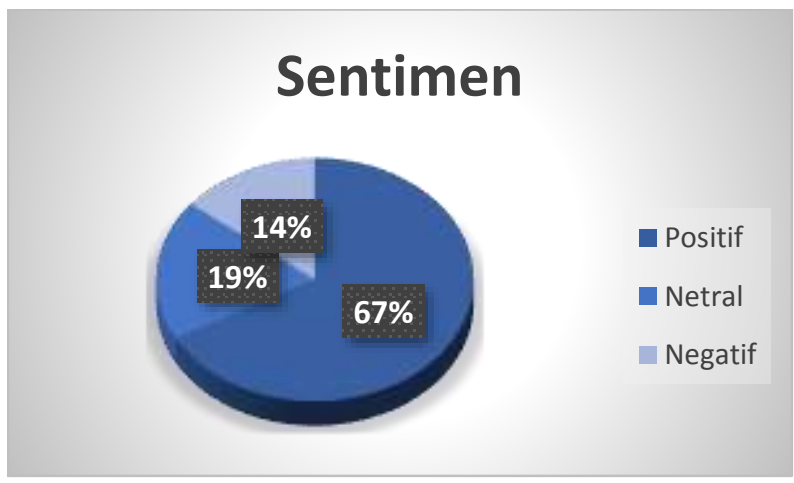

Gbr. 3 Hasil Analisis Sentimen dengan NBC

Berdasarkan Tabel VI, dapat dilihat nilai akurasi menurun perlahan seiring dengan bertambahnya jumlah fold. Nilai fold terbaik, yaitu 2 fold, dengan akurasi $67.2 \%$, rata-rata recall $71.31 \%$, rata-rata precision $75.64 \%$, dan waktu eksekusi selama 20 detik. Nilai akurasi paling rendah berada pada 10 fold, yaitu $60.94 \%$, dengan rata-rata recall dan precision secara berturut-turut $65.42 \%$ dan $72.06 \%$. Dengan demikian, analisis sentimen yang dipakai adalah 2 fold karena memiliki akurasi yang terbaik jika dibandingkan dengan nilai fold yang lain.

Hasil analisis sentimen yang diperoleh berdasarkan metode klasifikasi NBC dapat dilihat pada Gbr 3. Sentimen yang mendominasi pada data testing yang digunakan, yaitu positif dengan jumlah data 670 atau sebesar 67\%. Sedangkan sentimen netral sejumlah 187 data atau $19 \%$, serta sentimen negatif sejumlah 143 atau $14 \%$.

B. Analisis Data Menggunakan Support Vector Machine (SVM)
Pengujian SVM menggunakan data yang sama digunakan untuk pengujian dengan metode NBC. Pada proses pengujian ditambahkan salah satu operator pada RapidMiner, yaitu Polynomial by Binomial Classification karena SVM merupakan salah satu operator klasifikasi yang hanya memungkinkan untuk klasifikasi binomial sehingga tidak dapat diterapkan secara langsung untuk klasifikasi polynomial [25]. Hal ini perlu digunakan karena data pada penelitian ini termasuk polynomial karena memiliki 3 atribut atau sentimen, yaitu positif, negatif dan netral.

Pengujian pada proses SVM dilakukan sebanyak 8 kali dengan nilai fold pada cross validation yang sama pada NBC. Hasil pengujian dengan metode klasifikasi SVM pada data training dapat dilihat pada Tabel VII.

TABEL VII

PRESENTASE HASIL PENGUJIAN MENGGUNAKAN SVM

\begin{tabular}{|c|c|c|c|c|}
\hline K-Fold & Accuration & $\begin{array}{c}\text { Weighted } \\
\text { Mean } \\
\text { Recall }\end{array}$ & $\begin{array}{c}\text { Weighted Mean } \\
\text { Precision }\end{array}$ & $\begin{array}{c}\text { Execution } \\
\text { Time }\end{array}$ \\
\hline $\mathbf{2}$ & $81.67 \%$ & $81.67 \%$ & $80.96 \%$ & $1: 20$ detik \\
\hline $\mathbf{3}$ & $78.72 \%$ & $77.80 \%$ & $78.62 \%$ & $1: 36$ detik \\
\hline $\mathbf{4}$ & $79.02 \%$ & $77.58 \%$ & $79.51 \%$ & $2: 02$ detik \\
\hline $\mathbf{5}$ & $74.95 \%$ & $73.58 \%$ & $74.54 \%$ & $2: 41$ detik \\
\hline $\mathbf{6}$ & $75.89 \%$ & $74.51 \%$ & $75.38 \%$ & $3: 05$ detik \\
\hline $\mathbf{7}$ & $74.71 \%$ & $72.93 \%$ & $75.12 \%$ & $3: 36$ detik \\
\hline $\mathbf{8}$ & $73.84 \%$ & $71.73 \%$ & $73.62 \%$ & $6: 10$ detik \\
\hline $\mathbf{1 0}$ & $72.55 \%$ & $69.83 \%$ & $73.44 \%$ & \\
\hline
\end{tabular}

\section{Sentimen}

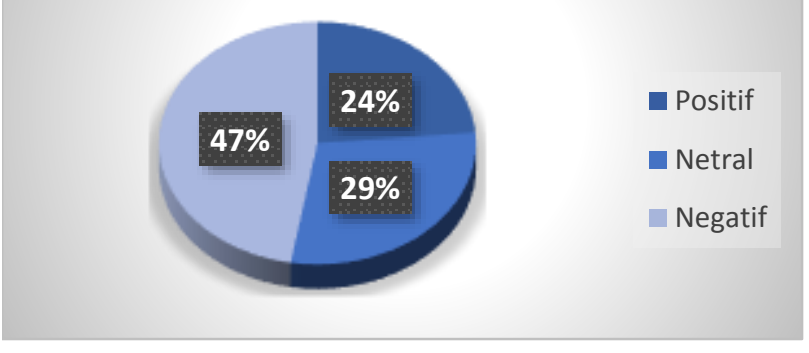

Gbr. 4 Hasil Analisis Sentimen dengan SVM

Berdasarkan hasil pengujian yang diperoleh pada Tabel VII, dapat diketahui nilai fold dengan akurasi terbaik berada pada 2 fold, yaitu $81.67 \%$. Hasil ini juga memiliki rata-rata recall dan precision yang baik, yaitu berturut-turut $81.67 \%$ dan $80.96 \%$ dengan waktu eksekusi selama 1:20 detik. Pada pengujian selanjutnya, tingkat akurasi mengalami penurunan dan sedikit peningkatan sesuai dengan nilai fold yang meningkat tetapi tidak melebihi akurasi dengan nilai 2 fold.

Hasil analisis sentimen yang diperoleh berdasarkan metode klasifikasi SVM dapat dilihat pada Gbr 4. Sentimen yang dihasilkan berdasarkan data testing, yaitu untuk sentimen negatif sejumlah 473 atau sebesar $47 \%$. Sedangkan sentimen 
netral sejumlah 291 atau sebesar $29 \%$, serta sentimen positif sejumlah 236 atau sebesar $24 \%$.

\section{Perbandingan NBC dan SVM}

Perbandingan hasil klasifikasi dengan metode klasifikasi SVM dan NBC dirangkum pada Tabel VIII.

TABEL VIII

PERBANDINGAN METODE NBC DAN SVM

\begin{tabular}{|c|c|l|l|l|}
\hline \multirow{2}{*}{ K-Fold } & \multicolumn{2}{|c|}{ NBC } & \multicolumn{2}{c|}{ SVM } \\
\cline { 2 - 5 } & Accuration & $\begin{array}{l}\text { Execution } \\
\text { Time }\end{array}$ & Accuration & $\begin{array}{l}\text { Execution } \\
\text { Time }\end{array}$ \\
\hline $\mathbf{2}$ & $67.20 \%$ & 20 detik & $81.67 \%$ & $1: 20$ detik \\
\hline $\mathbf{3}$ & $63.34 \%$ & 14 detik & $78.72 \%$ & $1: 36$ detik \\
\hline $\mathbf{4}$ & $62.73 \%$ & 12 detik & $79.02 \%$ & $2: 02$ detik \\
\hline $\mathbf{5}$ & $61.92 \%$ & 14 detik & $74.95 \%$ & $2: 41$ detik \\
\hline $\mathbf{6}$ & $61.34 \%$ & 13 detik & $75.89 \%$ & $3: 05$ detik \\
\hline $\mathbf{7}$ & $61.24 \%$ & 13 detik & $74.71 \%$ & $3: 36$ detik \\
\hline $\mathbf{8}$ & $61.01 \%$ & 20 detik & $73.84 \%$ & $4: 54$ detik \\
\hline $\mathbf{1 0}$ & $60.94 \%$ & 22 detik & $72.55 \%$ & $6: 10$ detik \\
\hline Avg. & $\mathbf{6 2 . 4 7} \%$ & & $\mathbf{7 6 . 4 2} \%$ & \\
\cline { 5 - 5 } & & & &
\end{tabular}

Berdasarkan hasil yang diperoleh pada Tabel VIII di atas dapat diketahui nilai fold yang paling baik diterapkan diantara kedua metode klasifikasi ini, yaitu 2 fold dengan akurasi pada NBC $67.2 \%$ dan akurasi pada SVM sebesar $81.67 \%$. Tingkat akurasi dari NBC dan SVM mengalami penurunan seiring dengan bertambahnya jumlah fold. Rata-rata tingkat akurasi yang diperoleh dengan 8 kali percobaan pada metode NBC yaitu sebesar $62.47 \%$, sedangkan percobaan menggunakan metode SVM sebesar $76.42 \%$.

Perbandingan akurasi diantara kedua metode ini menunjukkan metode SVM-lah yang memiliki nilai akurasi lebih baik daripada NBC. Hal yang berbeda ditemukan pada waktu eksekusi dimana metode SVM memiliki waktu eksekusi yang lebih lama dari pada metode NBC. Waktu proses eksekusi pada metode SVM juga semakin lama seiring dengan bertambahnya nilai fold.

Analisis sentimen dari kedua metode klasifikasi ini juga memiliki hasil yang berbeda, seperti yang terlihat pada Gambar 3 dan Gambar 4. Sentimen terhadap data tweet tentang masalah kelistrikan di Pulau Ambon dengan metode NBC didominasi oleh sentimen positif, yaitu sebesar $67 \%$. Sedangkan sentimen dengan metode SVM didominasi oleh sentimen negatif sebesar $47 \%$.

\section{KESIMPULAN}

Hasil penelitian yang telah dilakukan sebelumnya dapat menunjukkan bagaimana sentimen masyarakat di Pulau Ambon terhadap kondisi kelistrikan yang dikelola oleh Perusahaan Listrik Negara Cabang Ambon. Berdasarkan hasil penelitian tersebut dapat diketahui bahwa sentimen masyarakat cenderung positif jika menggunkan metode klasifikasi NBC dengan akurasi $67.20 \%$, tetapi hasilnya akan cenderung negatif jika menggunakan metode klasifikasi SVM dengan akurasi $81.67 \%$. Namun, dengan adanya hasil sentimen negatif dari kedua metode ini yang tidak lebih dari 50\%, dapat disimpulkan sentimen masyarakat di Pulau Ambon terhadap Perusahaan Listrik Negara Cabang Ambon cukup baik. Hal ini juga dipengaruhi oleh adanya layanana masyarakat, khususnya akun twitter@ambonlima yang mampu memberikan informasi secara realtime sehingga masyarakat dapat mengetahui alasan terjadinya pemadaman atau masalah kelistrikan lain yang terjadi.

Berdasarkan hasil penelitian yang dilakukan juga dapat disimpulkan bahwa proses pengujian pada $K$-Fold Cross Validation memiliki pengaruh dalam meningkatkan akurasi metode klasifikasi NBC dan SVM. Nilai fold terbaik yang digunakan pada proses klasifikasi, yaitu 2 fold karena menghasilkan tingkat akurasi yang lebih baik. Sedangkan jika dilihat berdasarkan waktu proses eksekusi, metode SVM lebih lama daripada metode NBC seiring dengan bertambahnya nilai fold. Hal ini dapat disebabkan oleh matriks vektor yang bertambah seiring dengan jumlah fold pada validasi serta pengaruh proses pada SVM yang harus dirubah ke klasifikasi polynomial agar dapat dieksekusi karena sifat dasarnya yang binomial.

Metode klasifikasi NBC pada analisis sentimen ini menghasilkan sentimen positif sebesar $67 \%$, sentimen netral $19 \%$, dan sentimen negatif $14 \%$. Hasil berbeda ditemukan jika menggunakan metode klasifikasi SVM, dimana sentimen negatif lebih besar dari sentimen netral dan positif. Sentimen negatif pada metode SVM sebesar 47\%, sentimen netral 29\%, dan sentimen positif $24 \%$. Hal ini menunjukkan bahwa algoritma yang berbeda pada proses klasifikasi dapat menghasilkan prediksi yang juga berbeda, dimana prediksi tersebut bisa saja benar tetapi juga bisa salah pada kasus lain. Hasil perbandingan metode klasifikasi analisis sentimen pada kasus ini menunjukkan metode SVM lebih baik daripada NBC, dengan tingkat akurasi sebesar $81.67 \%$. Sedangkan metode klasifikasi NBC hanya memiliki nilai akurasi sebesar $67.20 \%$ sehingga dapat diasumsikan bahwa metode SVM yang terbaik pada kasus ini.

Pengembangan selanjutnya dari penelitian ini perlu dilakukan, terutama untuk meningkatkan akurasi dari setiap metode klasifikasi yang digunakan. Misalnya pengujian akurasi menggunakan $n$-gram, dimana dalam pre-processing setiap kalimat dapat dibagi menjadi beberapa kata sesuai dengan nilai $n$. Selain itu, memasukan emoticon yang ada pada tweet juga dapat menjadi bahan pertimbangan untuk dimasukan kedalam pemrosesan data karena hal tersebut dapat menjadi representasi dari mood seseorang.

\section{DAFTAR PUSTAKA}

[1] APJII, "Penetrasi \& Perilaku Pengguna Internet Indonesia 2017," Asos. Penyelenggara Jasa Internet Indones., pp. 1-39, 2017.

[2] S. Kemp, "Digital in 2018 in Southeast Asia," We Are Soc., p. 362, 2018.

[3] PT Perusahaan Listrik Negara (Persero), Rencana Usaha Penyediaan Tenaga Listrik(RUPTL) PT PLN(Perserp) 2015 - 2024. Jakarta, 2015.

[4] W. He, S. Zha, and L. Li, "Social media competitive analysis and text mining: A case study in the pizza industry," Int. J. Inf. Manage., vol. 33, no. 3, pp. 464-472, 2013.

[5] R. Feldman and J. Sanger, The Text Mining Handbook. New York: Cambridge University Press, 2007.

[6] M. Kanakaraj and R. M. R. Guddeti, "Performance analysis of Ensemble methods on Twitter sentiment analysis using NLP techniques," Proc. 2015 IEEE 9th Int. Conf. Semant. Comput. IEEE ICSC 2015, pp. 169-170, 2015. 
[7] P. K. Gajakosh, G. Tushar, and S. Rajashri, "Opinion Mining for Multi-Mix Languages Hotel Review by using Fuzzy Sets," Int. Conf. Adv. Sci. Technol. 2015 (ICAST 2015) First, p. 4, 2015.

[8] C. C. Aggarwal and C. X. Zhai, A Survey of Text Classification Algorithms. In: Aggarwal C., Zhai C. (eds) Mining Text Data. Boston, MA: Springer, 2012.

[9] P. Tripathi, S. K. Vishwakarma, and A. Lala, "Sentiment Analysis of English Tweets Using RapidMiner," 2015 Int. Conf. Comput. Intell. Commun. Networks, pp. 668-672, 2015.

[10] S. K and D. R, "Designing a Machine Learning Based Software Risk Assessment Model Using Naïve Bayes Algorithm," TAGA J. Graph. Technol., vol. 14, pp. 3141-3147, 2018.

[11] N. Öztürk and S. Ayvaz, "Sentiment analysis on Twitter: A text mining approach to the Syrian refugee crisis," Telemat. Informatics, vol. 35, no. 1, pp. 136-147, 2018.

[12] I. Zulfa and E. Winarko, "Sentimen Analisis Tweet Berbahasa Indonesia Dengan Deep Belief Network," IJCCS (Indonesian J Comput. Cybern. Syst., vol. 11, no. 2, p. 187, 2017.

[13] B. Liu, Sentiment Analysis and Opinion Mining. Morgan \& Claypool Publishers, 2012.

[14] A. D'Andrea, F. Ferri, P. Grifoni, and T. Guzzo, "Approaches, Tools and Applications for Sentiment Analysis Implementation," Int. $J$. Comput. Appl., vol. 125, no. 3, pp. 26-33, 2015.

[15] S. B. Bhonde and J. R. Prasad, "Sentiment Analysis - Methods, Applications and Challenges," Int. J. Electron. Commun. Comput. Eng., vol. 6, no. 6Online, pp. 2249-71, 2015.

[16] M. Fernández-Gavilanes, T. Álvarez-López, J. Juncal-Martínez, E. Costa-Montenegro, and F. Javier González-Castaño, "Unsupervised method for sentiment analysis in online texts," Expert Syst. Appl., vol. 58, pp. 57-75, 2016

[17] Z. H. Deng, K. H. Luo, and H. L. Yu, "A study of supervised term weighting scheme for sentiment analysis," Expert Syst. Appl., vol. 41, no. 7, pp. 3506-3513, 2014.

[18] M. Lan, C. L. Tan, J. Su, and Y. Lu, "Supervised and Traditional Term Weighting Methods for Automatic Text Categorization," Pattern Anal. Mach. Intell. IEEE Trans., vol. 31, no. 4, pp. 721-735, 2009.

[19] R. Moraes, J. F. Valiati, and W. P. Gavião Neto, "Document-level sentiment classification: An empirical comparison between SVM and ANN," Expert Syst. Appl., vol. 40, no. 2, pp. 621-633, 2013.

[20] P. K. Singh and M. Shahid Husain, "Methodological Study Of Opinion Mining And Sentiment Analysis Techniques," Int. J. Soft Comput., vol. 5, no. 1, pp. 11-21, 2014

[21] E. Rish, "An empirical study of the naive Bayes classifier," IJCAI01 Work. Empir. Methods AI, no. January 2001, 2001.

[22] N. Yunita, "ANALISIS SENTIMEN BERITA ARTIS DENGAN MENGGUNAKAN ALGORITMA SUPPORT VECTOR MACHINE DAN PARTICLE SWARM OPTIMIZATION," J. Sist. Inf. STMIK Antar Bangsa, vol. V, no. 2, pp. 104-112, 2016.

[23] A. Amolik, N. Jivane, M. Bhandari, and M. Venkatesan, "Twitter sentiment analysis of movie reviews using machine learning technique," Int. J. Eng. Technol., vol. 7, no. 6, pp. 2038-2044, 2016. T. T. Wong, "Performance evaluation of classification algorithms by k-fold and leave-one-out cross validation," Pattern Recognit., vol. 48, no. 9, pp. 2839-2846, 2015.

[25] R. GmbH, RapidMiner 8 Operator Reference Manual. RapidMiner $\mathrm{GmbH}, 2018$. 